Márcia Perez Resende Oliveros

\title{
Prevalência e covariação de mutações relacionadas à resistência aos inibidores de protease no subtipo F do HIV-1
}

Dissertação apresentada à Faculdade de Medicina da Universidade de São Paulo para a obtenção do título de Mestre em Ciências

Área de concentração: Fisiopatologia Experimental Orientador: Dr. Luis Fernandez Lopez

SÃO PAULO

2005 
Márcia Perez Resende Oliveros

\section{Prevalência e covariação de mutações relacionadas à resistência aos inibidores de protease no subtipo F do HIV-1}

Dissertação apresentada à Faculdade de Medicina da Universidade de São Paulo para a obtenção do título de Mestre em Ciências

Área de concentração: Fisiopatologia Experimental Orientador: Dr. Luis Fernandez Lopez

SÃO PAULO

2005 
Ao Celso, pelo estímulo; aos meus pais, pelo apoio; e ao meu filho Gabriel, que chegou durante a execução do trabalho e foi uma grande fonte de inspiração. 


\section{AGRADECIMENTOS}

A Luis Fernandez Lopez pela orientação e pelo apoio.

Ao Dr. Ricardo Sobhie Dias pela atenção e colaboração.

Aos Drs. Ester Cerdeira Sabino, Edson Durigon e Koichi Sameshima pelas preciosas sugestões.

Ao pessoal do Laboratório de Retrovirologia da UNIFESP pela colaboração.

Aos colegas da Disciplina de Informática Médica pelo apoio e incentivo em todas as horas. 
As raras idéias verdadeiramente nossas são aquelas cuja semente não nos veio de outro espírito. E haverá alguma?

Joaquim Nabuco 


\section{RESUMO}

Cada subtipo de HIV-1 tem um padrão mutacional próprio. Dados sobre mutações de resistência aos antiretrovirais foram obtidos com o subtipo B, primeiro em prevalência no Brasil. O segundo em algumas regiões é o subtipo F. Foram analisados padrões mutacionais em seqüências brasileiras de protease do subtipo F e levantou as seqüências deste subtipo disponíveis na base de dados de Stanford. A análise de dois grupos de seqüências (pacientes não tratados e tratados com inibidores de protease) mostrou 19 mutações associadas ao tratamento comuns ao subtipo B e 17 duplas de mutações associadas ao tratamento que diferem das descritas para o subtipo B, indicando a necessidade de estudos sobre rotas mutacionais no subtipo F. 


\section{SUMMARY}

Each HIV-1 subtype has a specific mutation pattern. Data on HIV-1 antiretroviral resistance mutations were obtained with subtype $\mathrm{B}$, the first in prevalence in Brazil. The second in some regions is subtype F. Mutation patterns of Brazilian subtype F protease sequences were analyzed and performed a research of the sequences of Stanford Database. The analysis of two groups of sequences (untreated and treated patients with protease inhibitors) showed 19 treatment associated mutations also common in subtype B and 17 combinations of statistically treatment associated mutations that were quite different to those described for subtype B, indicating the need of studies to evaluate specific mutation pathways of subtype F. 